\title{
ENVIRONMENTAL DEGRADATION AND POLITICAL STABILITY: A COMPARATIVE STUDY OF GIVIL AND COMMON LAW DEVELOPING ECONOMIES
}

\author{
Alexandra-Anca PURCEL ${ }^{\text {a* }}$ \\ a) Babeș-Bolyai University, Faculty of Economics and Business Administration, \\ Cluj-Napoca, Romania and \\ Université Clermont Auvergne, CNRS, IRD, CERDI, Clermont-Ferrand, France
}

Please cite this article as:

Article History:

Purcel, A.A., 2020. Environmental degradation and political stability: A comparative study of civil and common law developing economies. Review of Economic Studies and Research Virgil Madgearu, 13(1), pp.93-113. doi: 10.24193/RVM.2020.13.54.

Abstract: Nowadays, environmental degradation and political stability are two of the most well-debated topics in the sphere of macroeconomics, which potentially have significant consequences on the welfare of society. This paper studies the impact of political stability on $\mathrm{CO}_{2}$ emissions in a comparative framework of civil and common law developing states. The findings based on the panel vector error correction model (PVECM) illustrate essential differences regarding the $\mathrm{CO}_{2}$ emissions-political stability nexus in our samples. Notably, we reveal a long-run monotonically increasing relationship in French legal origin economies, while a bell-shaped pattern is at work in English legal origin ones. Thus, a closer look at the political stability status in the context of environmental policy, in countries where the future levels of political stability are associated with a reduction in $\mathrm{CO}_{2}$ emission, may give valuable insights in fighting climate change.

Key words: $\mathrm{CO} 2$ emissions; political stability, French legal origin, English legal origin, developing states

JEL Classification: Q28; Q56; $\mathrm{O}_{13} ; \mathrm{P}_{48}$

(C) 2020 Alma Mater Publishing House. All rights reserved.

* Corresponding author.E-mail address: alexandra.purcel@econ.ubbcluj.ro. 


\section{References:}

1. Bae, J.H., Li, D.D., Rishi, M., 2017. Determinants of $\mathrm{CO} 2$ emission for post-Soviet Union independent countries. Climate Policy, 17, pp.591-615. 10.1080/14693062.2015.1124751.

2. Baltagi, B.H., Feng, Q., Kao, C., 2012. A Lagrange Multiplier test for cross-sectional dependence in a fixed effects panel data model. Journal of Econometrics, 170, pp.164-177. 10.1016/j. jeconom.2012.04.004.

3. Botero, J.C., Djankov, S., Porta, R.L., Lopez-de-Silanes, F., Shleifer, A., 2004. The Regulation of Labor. The Quarterly Journal of Economics, 119, pp.1339-1382. 10.1162/o033553042476215.

4. Breusch, T.S., Pagan, A.R., 1980. The Lagrange Multiplier Test and its Applications to Model Specification in Econometrics. The Review of Economic Studies, 47, pp.239-253. 10.2307/2297111.

5. Chudik, A.K., Mohaddes, Pesaran, M.H., Raissi, M., 2013. Debt, Inflation and Growth: Robust Estimation of Long-Run Effects in Dynamic Panel Data Model. CESifo Working Paper Series 4508, CESifo Group Munich [online] Available at: <http://www.dallasfed. org/assets/documents/institute/wpapers/2013/o162.pdf> [Accessed 20.02.2020].

6. Cole, M.A., 2007. Corruption, income and the environment: an empirical analysis. Ecological Economics, 62, pp.637-647.10.1016/j. ecolecon.2006.08.003.

7. Desai, U., (ed.) 1998. Ecological Policy and Politics in Developing Countries: Growth, Democracy and Environment. Albany: State University of New York Press.

8. Djankov, S., Glaeser, E., La Porta, R., Lopez-de-Silanes, F., Shleifer, A., 2003. The new comparative economics. Journal of Comparative Economics, 31, pp.595-619. 10.1016/j.jce.2003.08.005.

9. Djankov, S., La Porta, R., Lopez-de-Silanes, F., Shleifer, A., 2002. The Regulation of Entry. The Quarterly Journal of Economics, 117, pp.1-37. 10.1162/o03355302753399436.

10. Gani, A., 2012. The relationship between good governance and carbon dioxide emissions: evidence from developing economies. Journal of Economic Development, 37, pp.77-93. 10.35866/ caujed.2012.37.1.004. 
Purcel, Environmental Degradation and Political Stability...

11. Janssens-Maenhout, G., Crippa, M., Guizzardi, D., Muntean, M., Schaaf, E., Olivier, J.G.J., Peters, J.A.H.W., Schure, K.M., 2017. Fossil CO2 and GHG emissions of all world countries. [pdf] EUR 28766 EN, Publications Office of the European Union, Luxembourg. Available at: <https://edgar.jrc.ec.europa.eu/booklet2017/CO2 and_GHG_emissions_of_all_world_countries_booklet_online. pdf $>$ [Accessed 07.06.2019].

12. La Porta, R., Lopez-de-Silanes, F., Shleifer, A., 2008. The Economic Consequences of Legal Origins. Journal of Economic Literature, 46, pp.285-332. 10.3386/w13608.

13. La Porta, R., Lopez-de-Silanes, F., Shleifer, A., 2002. Government Ownership of Banks. Journal of Finance, 57, pp.265-301. 10.2139/ ssrn.236434

14. Landes, D., 1998. The wealth and poverty of nations, why some are so rich and some are so poor. New York: W.W. Norton and Company

15. Lazăr, D., Minea, A., Purcel, A.A., 2019. Pollution and economic growth: Evidence from central and eastern European countries. Energy Economics, 81, pp.1121-1131. 10.1016/j.eneco.2019.05.

16. López, R., Mitra, S., 2000. Corruption, Pollution, and the Kuznets Environment Curve. Journal of Environmental Economics and Management, 40, pp.137-150. 10.1006/jeem.1999.1107.

17. Mulligan, C.B., Shleifer, A., 2005a. Conscription as Regulation. American Law and Economics Review, 7, pp.85-111. 10.1093/aler/ ahioog.

18. Mulligan, C.B., Shleifer, A., 2005b. The Extent of the Market and the Supply of Regulation. Quarterly Journal of Economics, 120, pp.1445-1473. 10.1162/o03355305775097579.

19. North, D.C., 2000. Summerhill, W., Weingast, B.R., 2000. Order, disorder and economic change: Latin America vs. North America. In: B.B. De Mesquita, and H. Root, eds. 2000. Governing for Prosperity. New Haven: Yale University Press. 9, pp.16-58.

20. Pesaran, H.M., 2003. A simple panel unit root test in the presence of cross section dependence. [pdf] Cambridge WP in Economics, no. 0346, University of Cambridge. Available at: <http://www.econ. cam.ac.uk/research-files/repec/cam/pdf/cwpeo346.pdf $>$ [Accessed 23.06.2019].

21. Pesaran, H.M., 2004. General diagnostic tests for cross section dependence in panels. [pdf] Discussion Paper No. 1240, The 
Institute for the Study of Labor (IZA). Available at: <http://ftp.iza. org/dp1240.pdf> [Accessed 23.06.2019].

22. Pesaran, H.M., Smith, R., 1995. Estimating long-run relationships from dynamic heterogeneous panels. Journal of Econometrics, 68, pp.79-113. 10.1016/0304-4076(94)01644-f.

23. Pesaran, H.M., Shin, Y., Smith, R.P., 1999. Pooled mean group estimation of dynamic heterogeneous panels. Journal of the American Statistical Association, 94, pp.621-634. 10.2307/2670182.

24. Political Risk Services Group, 2019. International Country Risk Guide. [online] Available at: <https://www.prsgroup.com/explore-ourproducts/international-country-risk-guide/> [Accessed 15.06.2019].

25. Purcel, A.A., 2019. Does Political Stability Hinder Pollution? Evidence From Developing States. Economic Research Guardian, 9(2), pp.75-98.

26. Welsch, H., 2004. Corruption, growth, and the environment: a cross-country analysis. Environment and Development Economics, 9, pp.663-693. 10.1017/s1355770x04001500.

27. Westerlund, J., 2007. Testing for error correction in panel data. Oxford Bulletin of Economics and Statistics, 69, pp.709-748.

28. Williamson, J.B., Fleming, J.J., 1977. Convergence Theory and the Social Welfare Sector. Comparative Sociology, 18, pp.242-253. 